\title{
Zoonotic Vectorborne Pathogens and Ectoparasites of Dogs and Cats in Eastern and Southeast Asia
}

\author{
Vito Colella, Viet L. Nguyen, Do Y. Tan, Na Lu, Fang Fang, Yin Zhijuan, Jiangwei Wang, Xin Liu, \\ Xinghui Chen, Junyan Dong, Wisnu Nurcahyo, Upik K. Hadi, Virginia Venturina, Kenneth B.Y. Tong, \\ Yi-Lun Tsai, Piyanan Taweethavonsawat, Saruda Tiwananthagorn, Thong Q. Le, Khanh L. Bui, \\ Malaika Watanabe, Puteri A.M.A. Rani, Giada Annoscia, Frédéric Beugnet, Domenico Otranto, Lénaïg Halos
}

To provide data that can be used to inform treatment and prevention strategies for zoonotic pathogens in animal and human populations, we assessed the occurrence of zoonotic pathogens and their vectors on 2,381 client-owned dogs and cats living in metropolitan areas of 8 countries in eastern and Southeast Asia during 2017-2018. Overall exposure to ectoparasites was $42.4 \%$ in dogs and $31.3 \%$ in cats. Our data cover a wide geographic distribution of several pathogens, including Leishmania infantum and zoonotic species of filariae, and of animals infested with arthropods known to be vectors of zoonotic pathogens. Because dogs and cats share a common environment with humans, they are likely to be key reservoirs of pathogens that infect persons in the same environment. These results will help epidemiologists and policy makers provide tailored recommendations for future surveillance and prevention strategies.

sia is the largest continent in the world, known
for its thriving biocultural diversity. Today,
countries in Asia are experiencing a rapid social, de-
mographic, and economic transformation, thereby
placing this region as an ever-growing economic
powerhouse in the years to come. Sustained eco-
nomic growth in Asia has resulted in increased

Author affiliations: University of Melbourne, Melbourne, Victoria, Australia (V. Colella); University of Bari, Bari, Italy (V. Colella, V.L. Nguyen, G. Annoscia, D. Otranto); Boehringer Ingelheim Animal Health, Lyon, France (D.Y. Tan, Na Lu, F. Beugnet, L. Halos); Guangxi University, Nanning, China (F. Fang); KangBao Pet Hospital, Guilin, China (Y. Zhijuan); Sapphire Veterinary Hospital, Shanghai, China (J. Wang); Meilianzhonghe Veterinary Referral Center, Beijing, China (X. Liu); Chongyisheng Veterinary Hospital, Chengdu, China (X. Chen); Nanjing Police Dog Research Institute, Nanjing, China (J. Dong); Gadjah Mada University, Yogyakata, Indonesia (W. Nurcahyo); Bogor University demand for products and services and substantial urbanization (1). These factors have triggered a series of human-mediated environmental alterations, such as deforestation and encroachment of humans into natural ecosystems, that now link previously isolated ecologic niches and give pathogens new opportunities to thrive (2). During the past century, Asia has been in the limelight for emergence and pathogenicity of a large number of infectious diseases that have taken a substantial toll on the health of millions of persons (1). Striking examples include the emergence of severe acute respiratory syndrome, infections with the highly pathogenic avian influenza $\mathrm{A}(\mathrm{H} 5 \mathrm{~N} 1)$ virus, and coronavirus disease (COVID-19). Recently, human modification of natural habitats resulted in the emergence of a tick vector of Kyasanur Forest disease virus, a zoonotic vectorborne flavivirus that causes severe hemorrhagic fever with a fatality rate of $3 \%-10 \%$ (3).

Also implicated in the changing epidemiology of pathogens of public health concern in eastern and Southeast Asia are dogs and cats (4-6). In remote areas of eastern and Southeast Asia, three quarters of dogs are classified as stray or community dogs (7). Increases in living standards have led to a dramatic
Indonesia, Jakarta, Indonesia (U.K. Hadi); Central Luzon State University, Nueva Ecija, Philippines (V. Venturina); Animal \& Avian Veterinary Clinic, Yishun, Singapore (K.B.Y. Tong); National Pingtung University of Science and Technology, Pingtung, Taiwan (Y.L. Tsai); Chulalongkorn University, Bangkok, Thailand (P. Taweethavonsawat); Chiang Mai University, Chiang Mai, Thailand (S. Tiwananthagorn); Nong Lam University, Ho Chi Minh City, Vietnam (T.Q. Le); Vietnam National University of Agriculture, Hanoi, Vietnam (K.L. Bui); University Putra Malaysia, Selangor, Malaysia (M. Watanabe, P.A.M.A. Rani)

DOI: https://doi.org/10.3201/eid2606.191832 


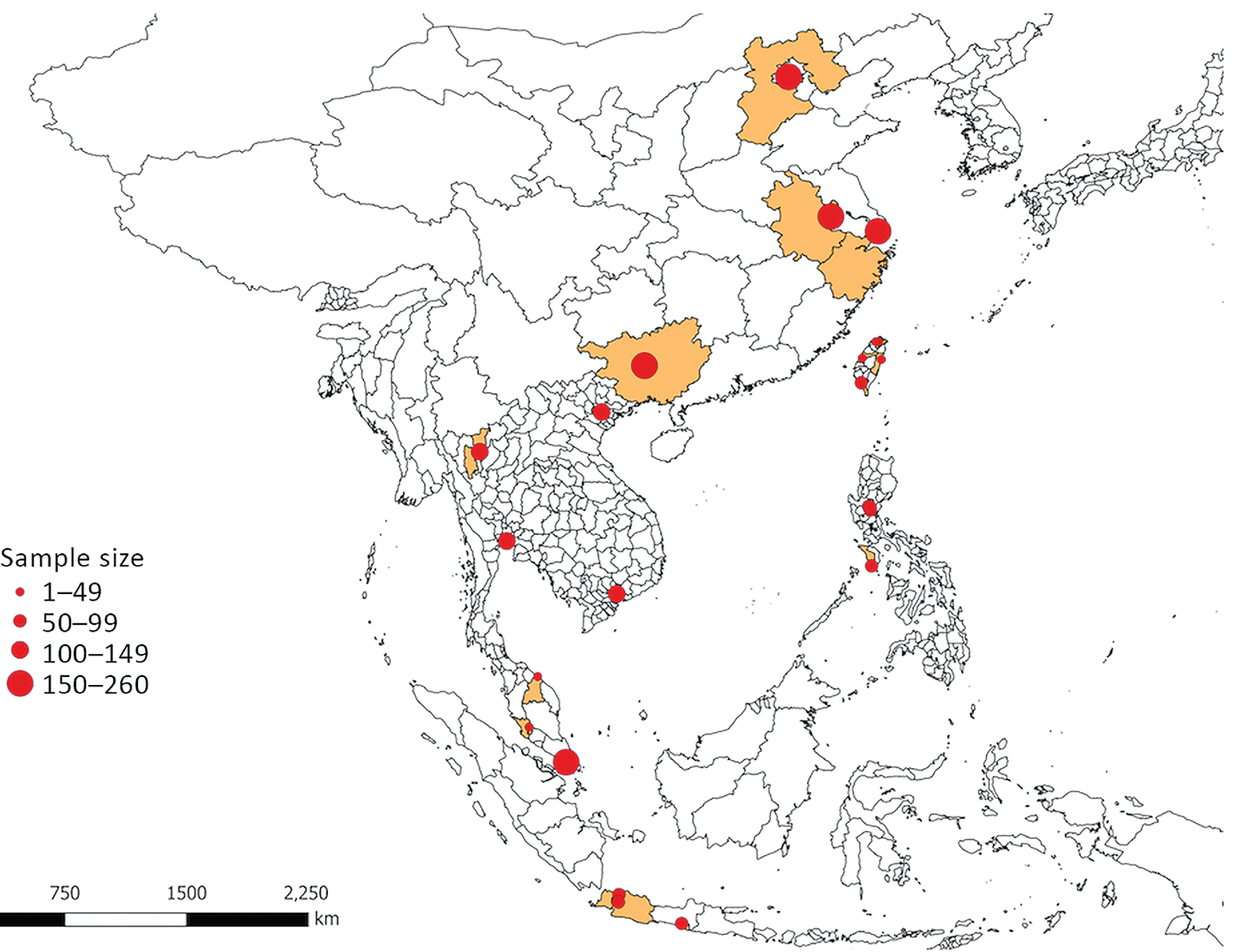

Figure 1. Geographic distribution and size of dog and cat samples in study of ectoparasites and vectorborne zoonotic pathogens of dogs and cats in Asia, 2017-2018. Highlighted areas represent the geographic regions from which samples were collected in China, Indonesia, Malaysia, the Philippines, Singapore, Taiwan, Thailand, and Vietnam.

surge in the number of pet dogs and cats living in metropolitan settings $(8,9)$. In China, the population of pet dogs is estimated to grow by 5 million per year. Along with this increase in companion animal ownership, the risk of acquiring parasitic zoonoses from companion dogs and cats represents an ongoing, yet neglected, threat $(10,11)$.

Implementation of effective measures to control zoonotic diseases must rely on the elucidation of pathogens and reservoir hosts in a given area. For most countries in Asia, limited knowledge about the agents parasitizing dogs and cats, including those transmissible to humans, hinders the establishment of proper strategies for treatment and prevention of zoonotic pathogens in animal and human populations. Although previous investigations have explored the occurrence of zoonotic diseases in animals living in remote areas (4-7), our year-long multicenter study explored the occurrence of vectorborne pathogens and ectoparasites in pet dogs and cats from metropolitan areas in eastern and Southeast Asia.

\section{Methods}

Our study involved academic institutions and private facilities of eastern Asia (China and Taiwan) and Southeast Asia (Indonesia, Malaysia, the Philippines, Singapore, Thailand, and Vietnam). To provide capacity building and compliance with the study procedures, trainings were performed at local institutions as needed. The protocol of this study was approved by the Ethics Committee of the Department of Veterinary Medicine, University of Bari (protocol no. 13/17). At partner institutions, animal owners read, approved, and signed an owner informed consent, which contained information about study procedures.

During 2017-2018, local investigators sampled 10 client-owned dogs and 10 client-owned cats each month for 12 months in each country, except China, 
Table 1. Distribution of 1,229 dogs and 1,152 cats from select countries, by age group, husbandry, and sex, in study of ectoparasites and vectorborne zoonotic pathogens of dogs and cats, Asia, 2017-2018

\begin{tabular}{|c|c|c|c|c|c|c|c|c|c|c|c|c|c|c|}
\hline \multirow{3}{*}{$\begin{array}{l}\text { Country (total no. } \\
\text { animals; no. dogs, } \\
\text { no. cats) }\end{array}$} & \multicolumn{6}{|c|}{ Age, y } & \multicolumn{4}{|c|}{ Husbandry } & \multicolumn{4}{|c|}{ Sex } \\
\hline & \multicolumn{2}{|c|}{$\leq 1$} & \multicolumn{2}{|c|}{$>1$ to $\leq 5$} & \multicolumn{2}{|c|}{$>5$} & \multicolumn{2}{|c|}{ Urban area } & \multicolumn{2}{|c|}{ Rural area } & \multicolumn{2}{|c|}{$M$} & \multicolumn{2}{|c|}{$\mathrm{F}$} \\
\hline & Dogs & Cats & Dogs & Cats & Dogs & Cats & Dogs & Cats & Dogs & Cats & Dogs & Cats & Dogs & Cats \\
\hline $\begin{array}{l}\text { China }(971 ; 481 \\
490)^{*}\end{array}$ & 122 & 228 & 182 & & 172 & 69 & 464 & 484 & 17 & 6 & 289 & 273 & 192 & 217 \\
\hline $\begin{array}{l}\text { Indonesia (173; 95, } \\
78)\end{array}$ & 30 & 22 & 50 & 46 & 15 & 10 & 68 & 63 & 27 & 15 & 51 & 39 & 44 & 39 \\
\hline Malaysia $(91 ; 45,46)$ & 9 & 30 & 11 & 14 & 25 & 2 & 45 & 1 & 0 & 45 & 20 & 27 & 25 & 19 \\
\hline $\begin{array}{l}\text { Philippines (235; } \\
120,115)\end{array}$ & 45 & 50 & 50 & 59 & 20 & 5 & 96 & 91 & 24 & 23 & 51 & 60 & 68 & 54 \\
\hline $\begin{array}{l}\text { Singapore }(245 ; \\
116,129)\end{array}$ & 3 & 61 & 14 & 26 & 98 & 42 & 115 & 128 & 1 & 1 & 50 & 67 & 63 & 60 \\
\hline $\begin{array}{l}\text { Taiwan (186; } \\
132,54)\end{array}$ & 10 & 26 & 45 & 20 & 77 & 8 & 81 & 35 & 51 & 19 & 62 & 28 & 69 & 26 \\
\hline $\begin{array}{l}\text { Thailand }(240 ; 120 \text {, } \\
\text { 120) }\end{array}$ & 15 & 35 & 49 & 66 & 54 & 19 & 89 & 101 & 31 & 19 & 69 & 49 & 51 & 71 \\
\hline $\begin{array}{l}\text { Vietnam }(240 ; 120, \\
120)\end{array}$ & 48 & 80 & 49 & 27 & 20 & 0 & 81 & 86 & 39 & 19 & 66 & 63 & 53 & 57 \\
\hline $\begin{array}{l}\text { All }(2,381 ; 1,229, \\
1,152)\end{array}$ & 282 & 532 & 450 & 451 & 481 & 155 & 1,039 & 989 & 190 & 147 & 658 & 606 & 565 & 543 \\
\hline
\end{tabular}

where 40 dogs and 40 cats each month were sampled. Inclusion criteria were a history of regular outdoor access and having not received recent antiparasitic treatments. Data on the animals' location, age, breed, and sex were recorded.

\section{Veterinary Examination}

Veterinarians performed a complete examination of the animals, reporting abnormalities in rectal temperature, overall physical condition, demeanor, nasal discharge, skin/haircoat, eyes, superficial lymph nodes, respiratory system (breathing), cardiovascular system (mucous membranes), and fecal consistency. The examinations included checking for the presence of ectoparasites (ticks, fleas, lice, and mites) by examining the whole-body surface for $\geq 5$ minutes. The veterinarians inspected both eyes, including a thorough examination under the third eyelid to detect adult Thelazia callipaeda eyeworms. They also performed testing for lesions evocative of sarcoptic mange or demodicosis (deep skin scraping), cheyletiellosis (tape test), or otoacariosis (earwax examination).

Sampled parasites were stored in vials containing 70\% ethanol and sent for morphologic and molecular identification at the University of Bari (Bari, Italy), where we examined adult and nymph ticks under a stereomicroscope. We clarified tick larvae, fleas, lice, and fur mites in $10 \%$ potassium hydroxide overnight, mounted in Hoyer's medium and observed under an optical microscope (12). We

Table 2. Frequency of tick, flea, and lice detection on 1,229 dogs and 1,152 cats, by country, in study of ectoparasites and vectorborne zoonotic pathogens of dogs and cats, Asia, 2017-2018

\begin{tabular}{|c|c|c|c|c|c|c|}
\hline \multirow{3}{*}{$\begin{array}{l}\text { Country (no. } \\
\text { dogs, no. cats) }\end{array}$} & \multicolumn{6}{|c|}{ Detection frequency, $\%(95 \% \mathrm{Cl})$} \\
\hline & \multicolumn{2}{|c|}{ Ticks } & \multicolumn{2}{|c|}{ Fleas } & \multicolumn{2}{|c|}{ Lice } \\
\hline & Dogs & Cats & Dogs & Cats & Dogs & Cats \\
\hline $\begin{array}{l}\text { China (481, } \\
490)\end{array}$ & $6.0(4.2-8.5)$ & $0.2(0.0-1.1)$ & $3.1(1.9-5.1)$ & $4.5(3.0-6.7)$ & $0.6(0.2-1.8)$ & $0.8(0.0-2.0)$ \\
\hline $\begin{array}{l}\text { Indonesia (95, } \\
78)\end{array}$ & $42.1(32.7-52.2)$ & $10.3(5.3-18.9)$ & $16.8(10.6-25.6)$ & $53.9(42.9-64.5)$ & $6.3(2.9-13.1)$ & $33.3(23.9-44.4)$ \\
\hline $\begin{array}{l}\text { Malaysia (45, } \\
46)\end{array}$ & $4.4(1.2-14.8)$ & 0 & $4.4(1.2-14.8)$ & $89.1(77.0-95.3)$ & 0 & $8.7(3.4-20.3)$ \\
\hline $\begin{array}{l}\text { Philippines } \\
(120,115)\end{array}$ & $67.5(58.7-75.2)$ & $24.4(17.4-32.9)$ & $80.0(72.0-86.2)$ & $54.8(45.7-63.6)$ & $52.5(43.6-61.2)$ & $26.1(18.9-34.8)$ \\
\hline $\begin{array}{l}\text { Singapore } \\
(116,129)\end{array}$ & $8.6(4.7-15.1)$ & $1.6(0.4-5.5)$ & $0.9(0.0-4.7)$ & $3.9(1.7-8.7)$ & $0.9(0.0-4.7)$ & $3.9(1.7-8.7)$ \\
\hline $\begin{array}{l}\text { Taiwan (132, } \\
54)\end{array}$ & $12.9(8.2-19.7)$ & $5.6(1.9-15.1)$ & $9.1(5.3-15.2)$ & $20.4(11.8-32.9)$ & $0.8(0.0-4.2)$ & $1.9(0.3-9.7)$ \\
\hline $\begin{array}{l}\text { Thailand (120, } \\
120)\end{array}$ & $27.5(20.3-36.1)$ & 0 & $20.8(14.5-28.9)$ & $19.2(13.1-27.1)$ & $2.5(0.8-7.1)$ & 0 \\
\hline $\begin{array}{l}\text { Vietnam (120, } \\
120)\end{array}$ & $51.7(42.8-60.4)$ & $0.8(0.1-4.6)$ & $12.5(7.7-19.6)$ & $15.8(10.4-23.4)$ & $0.8(0-4.6)$ & 0 \\
\hline $\begin{array}{l}\text { All }(1,229, \\
1152)\end{array}$ & $22.3(20.1-24.7)$ & $3.7(2.8-5.0)$ & $14.8(12.9-16.9)$ & $19.6(17.4-22.0)$ & $6.4(5.1-7.8)$ & $6.1(4.8-7.6)$ \\
\hline
\end{tabular}


Table 3. Frequency of mite detection on 1,229 dogs and 1,152 cats in study of ectoparasites and vectorborne zoonotic pathogens of dogs and cats, Asia, 2017-2018

\begin{tabular}{|c|c|c|c|c|c|c|c|}
\hline \multirow{4}{*}{$\begin{array}{l}\text { Country (no. dogs, } \\
\text { no. cats) }\end{array}$} & \multicolumn{7}{|c|}{ Detection frequency, $\%(95 \% \mathrm{Cl})$} \\
\hline & \multicolumn{2}{|c|}{ Scabies mites } & \multirow{2}{*}{\multicolumn{2}{|c|}{ Demodex spp. }} & & & \multirow{3}{*}{$\begin{array}{l}\text { Lynxacarus } \\
\text { radovskyi, cats }\end{array}$} \\
\hline & \multirow{2}{*}{$\begin{array}{c}\text { Sarcoptes } \\
\text { scabiei, dogs }\end{array}$} & \multirow{2}{*}{$\begin{array}{c}\text { Notoedres cati, } \\
\text { cats }\end{array}$} & & & \multicolumn{2}{|c|}{ Otodectes cynotis } & \\
\hline & & & Dogs & Cats & Dogs & Cats & \\
\hline China $(481,490)$ & $0.6(0.2-1.8)$ & $0.2(0-1.1)$ & $\begin{array}{c}0.6 \\
(0.2-1.8)\end{array}$ & $\begin{array}{c}0.2 \\
(0-1.1)\end{array}$ & $\begin{array}{c}1.3 \\
(0.6-2.7)\end{array}$ & $\begin{array}{c}5.1 \\
(3.5-7.4)\end{array}$ & 0 \\
\hline Indonesia $(95,78)$ & $3.2(1.1-8.9)$ & $34.6(25.0-45.7)$ & $\begin{array}{c}1.1 \\
(0.2-5.7)\end{array}$ & 0 & 0 & $\begin{array}{c}12.8 \\
(7.1-22.0)\end{array}$ & $5.1(2.0-12.5)$ \\
\hline Malaysia $(45,46)$ & 0 & 0 & 0 & 0 & 0 & $\begin{array}{c}17.4 \\
(9.09-30.72)\end{array}$ & $4.4(1.2-1.45)$ \\
\hline $\begin{array}{l}\text { Philippines (120, } \\
\text { 115) }\end{array}$ & 0 & $0.9(0.1-4.7)$ & $\begin{array}{c}3.3 \\
(1.3-8.3)\end{array}$ & $\begin{array}{c}0.9 \\
(0.1-4.7)\end{array}$ & 0 & $\begin{array}{c}2.6 \\
(0.9-7.4)\end{array}$ & 0 \\
\hline $\begin{array}{l}\text { Singapore (116, } \\
129)\end{array}$ & $2.7(0.5-6.1)$ & 0 & $\begin{array}{c}4.3 \\
(1.8-9.7)\end{array}$ & 0 & $\begin{array}{c}0.9 \\
(0.1-4.7)\end{array}$ & $\begin{array}{c}19.4 \\
(13.5-27.0)\end{array}$ & $34.9(27.2-43.4)$ \\
\hline Taiwan $(132,54)$ & 0 & 0 & $\begin{array}{c}0.2 \\
(0.04-5.4)\end{array}$ & 0 & $\begin{array}{c}2.3 \\
(0.8-6.5)\end{array}$ & $\begin{array}{c}7.4 \\
(2.9-17.5)\end{array}$ & 0 \\
\hline Thailand $(120,120)$ & 0 & 0 & 0 & 0 & 0 & $\begin{array}{c}1.7 \\
(0.0-5.8)\end{array}$ & 0 \\
\hline Vietnam $(120,120)$ & $0.8(0.1-4.6)$ & 0 & $\begin{array}{c}2.5 \\
(0.8-7.1)\end{array}$ & 0 & $\begin{array}{c}0.8 \\
(0.1-4.6)\end{array}$ & $\begin{array}{c}10 \\
(5.8-16.7)\end{array}$ & 0 \\
\hline All $(1,229,1,152)$ & $0.7(0.4-1.4)$ & $2.5(1.7-3.4)$ & $\begin{array}{c}1.5 \\
(0.9-2.3)\end{array}$ & $\begin{array}{c}0.2 \\
(0-0.6)\end{array}$ & $\begin{array}{c}0.9 \\
(0.5-1.6)\end{array}$ & $\begin{array}{c}7.7 \\
(6.3-9.4)\end{array}$ & $4.4(3.4-5.6)$ \\
\hline
\end{tabular}

used morphologic keys to identify all ectoparasites to the species level (13-20). For mite identification, we minced crusty skin lesions by using disposable surgical blades, added drops of saline solution on a glass slide, observed the slides under an optical microscope, and identified the mites according to morphologic appearance $(18,21)$. We mounted anterior and posterior extremities of adult T. callipaeda eyeworms in lactophenol and identified them (22).

\section{Molecular Identification of Ectoparasites}

To confirm morphologic identifications of ectoparasite species, we subjected a representative subpopulation $(\approx 20 \%)$ of the ectoparasites to DNA extraction and amplification of target genes (Appendix Table, https://wwwnc.cdc.gov/EID/article/26/6/19-1832App1.pdf). For ticks, fleas and lice, we isolated genomic DNA (gDNA) by using the DNeasy Blood and Tissue Kit (QIAGEN, https:/ / www.qiagen.com) according to the manufacturer's instructions. We isolated gDNA from a small portion of the idiosoma of ticks (23) and from the anterior dorsal part of the abdomen of fleas (24). We selected individual lice and mites under an optical microscope and extracted gDNA by using a QIAamp DNA Micro Kit (QIAGEN).

\section{Blood Collection and Processing}

From each study animal, we collected $\approx 2 \mathrm{~mL}$ of blood in a tube with anticoagulant and processed it as follows. For dogs, we used an aliquot of the blood sample for the ELISA-based technology SNAP 4Dx Plus test (IDEXX Laboratories, Inc., https://www.idexx.com) to detect Dirofilaria immitis antigen and antibodies against Anaplasma phagocytophilum/A. platys, Borrelia burgdorferi sensu lato, and Ehrlichia canis/E. ewingii as described and the SNAP Leishmania test (IDEXX Laboratories, Inc.) to detect antibodies against Leishmania infantum/L. donovani as described. For cats, we used an aliquot of blood to detect antigens of feline leukemia virus (FeLV) and D. immitis and antibodies against feline immunodeficiency virus (FIV). We used the SNAP Combo FIV/FeLV and SNAP Heartworm RT Test (IDEXX Laboratories, Inc.). For dogs and cats, we blotted 2 spots of blood $(125 \mu \mathrm{L}$ each, total $250 \mu \mathrm{L} /$ animal) onto Whatman FTA cards (Sigma-Aldrich Corp., https://www.sigmaaldrich.com), stored the cards overnight $(\geq 6 \mathrm{~h}$ ) at room temperature for blood to dry, and put them in a zip-locked plastic bag.

\section{DNA Extraction, Amplification, Purification, and Sequencing}

From each Whatman FTA card, we punched out 5 disks of 3.0-mm each (Uni-Core 150 punch; GE Healthcare, https://www.gelifesciences.com) and placed them in each well of a 96-well plate (QIAcube HT kit Plasticware; QIAGEN) and included a negative control (Whatman FTA card blotted with dog blood naive to the pathogens in this study) for each plate. Subsequently, we added a $200-\mu \mathrm{L}$ solution (180 $\mu \mathrm{L}$ of buffer ATL and $20 \mu \mathrm{L}$ of proteinase $\mathrm{K}$ ) to each well and subjected samples to prelysate overnight incubation at $56^{\circ} \mathrm{C}$ in a $711 \mathrm{CT}$ incubator (Asal s.r.l., http://www.asal.it). We extracted DNA by using a QIAcube HT and the QIAamp 96 DNA QIAcube HT 
kit (QIAGEN) according to manufacturer instructions. We tested all gDNA isolated from dried blood samples by conventional PCR (cPCR) (Appendix Table). We detected Leishmania protozoa by quantitative PCR (qPCR) and further tested only samples scoring positive in duplicates by qPCR by CPCR on the internal transcribed spacer 2 region and kinetoplast DNA for species identification (Appendix Table).

For all PCRs, we included positive controls (DNA of pathogen-positive blood samples) and negative controls (DNA of pathogen-negative blood samples). We visualized PCR amplicons from nematodes and apicomplexan protozoa by capillary electrophoresis by using a QIAxcel DNA screening gel cartridge on a
QIAxcel system (QIAGEN for each) and used a QX DNA Size Marker (QIAGEN) to size PCR products. We injected a QX Alignment Marker (QIAGEN), which consisted of 15-bp and 3,000-bp fragments, onto the cartridge with each sample. We then determined the PCR product sizes by using QIAxcel Screen Gel 1.4.0 software (QIAGEN). We subjected cPCR products from Leishmania spp. protozoa, Thelazia spp. eyeworms, ticks, fleas, lice, and mites to electrophoresis in a $2 \%$ agarose gel stained with Gel Red (VWR International PBI, https://it.vwr. com) and visualized them on a Kodak Gel Logic 100 gel documentation system (https://www.kodak.com).

We purified all cPCR amplicons obtained and sequenced them in both directions in an automated

\begin{tabular}{|c|c|c|c|c|c|}
\hline \multirow[b]{2}{*}{ Ectoparasite } & \multicolumn{2}{|c|}{ Location } & \multicolumn{2}{|c|}{ Relative frequency of occurrence, $\%(95 \% \mathrm{Cl})$} & \multirow{2}{*}{$\begin{array}{c}\text { GenBank accession } \\
\text { nos. }\end{array}$} \\
\hline & Dogs & Cats & Dogs & Cats & \\
\hline \multicolumn{6}{|l|}{ Tick } \\
\hline $\begin{array}{l}\text { Rhipicephalus } \\
\text { sanguineus }\end{array}$ & All countries & $\begin{array}{l}\text { Philippines, } \\
\text { Singapore, } \\
\text { Indonesia, } \\
\text { Taiwan, China }\end{array}$ & 96.6 (93.6-98.2) & $95(83.5-98.6)$ & $\begin{array}{l}\text { MN685287-321, } \\
\text { MT320104-5 }\end{array}$ \\
\hline R. haemaphysaloides & & Taiwan & $0.8(0.2-2.7)$ & & MN653239-40 \\
\hline Haemaphysalis hystricis & Thailand & & $0.4(0-2.1)$ & & MN658833 \\
\hline H. wellingtoni & $\begin{array}{l}\text { Thailand, } \\
\text { Indonesia }\end{array}$ & & $0.8(0.2-2.7)$ & & MN658820-1 \\
\hline H. campanulata & China & & $0.4(0-2.1)$ & & MN658817 \\
\hline H. longicornis & China & China & $0.8(0.2-2.7)$ & $2.5 \%(0.4-12.9)$ & MN658797-800 \\
\hline Ixodes sp. & & Taiwan & & $2.5(0.4-12.9)$ & МT035959 \\
\hline \multicolumn{6}{|l|}{ Fleas } \\
\hline Ctenocephalides felis & All & All & $65.1(57.7-71.8)$ & 98.7 (95.5-99.6) & $\begin{array}{c}\text { MT027205-8, } \\
\text { MT027227, MT027230 }\end{array}$ \\
\hline C. canis & $\begin{array}{l}\text { Vietnam, } \\
\text { Philippines, } \\
\text { Indonesia, } \\
\text { China }\end{array}$ & Philippines & $15.7(22.0-21.9)$ & $0.6(0.1-3.5)$ & Not applicable \\
\hline C. orientis & $\begin{array}{l}\text { Vietnam, } \\
\text { Thailand, } \\
\text { Philippines, } \\
\text { Singapore, } \\
\text { Indonesia, } \\
\text { Taiwan }\end{array}$ & & $19.2(14.0-25.7)$ & & МT027193-99 \\
\hline Xenopsylla cheopis & & Indonesia & & $0.6(0.1-3.5)$ & MT027228 \\
\hline \multicolumn{6}{|l|}{ Lice } \\
\hline Heterodoxus spiniger & $\begin{array}{c}\text { Vietnam, } \\
\text { Thailand, } \\
\text { Philippines, } \\
\text { Taiwan, } \\
\text { China }\end{array}$ & & 72.8 (63.5-80.5) & & МT027225 \\
\hline Trichodectes canis & $\begin{array}{l}\text { Philippines, } \\
\text { Singapore, } \\
\text { Indonesia }\end{array}$ & & $25.2(17.8-34.4)$ & & MT027226 \\
\hline Felicola subrostratus & Indonesia & $\begin{array}{l}\text { Philippines, } \\
\text { Indonesia, } \\
\text { China }\end{array}$ & $1.9(0.5-6.8)$ & $1.8(0.3-9.3)$ & Not applicable \\
\hline Linognathus setosus & & Malaysia & & & Not applicable \\
\hline \multicolumn{6}{|l|}{ Mites } \\
\hline Lynxacarus radovskyi & & $\begin{array}{l}\text { Singapore, } \\
\text { Malaysia, } \\
\text { Indonesia }\end{array}$ & Not applicable & Not applicable & MN639734, MN639736 \\
\hline
\end{tabular}


Table 5. Serologic and molecular detection of vectorborne pathogens in dogs in study of ectoparasites and vectorborne zoonotic pathogens of dogs and cats, Asia, 2017-2018*

\begin{tabular}{|c|c|c|c|c|c|}
\hline \multirow[b]{2}{*}{ Country } & \multicolumn{5}{|c|}{ Detection frequency, \% $(95 \% \mathrm{Cl})$} \\
\hline & $\begin{array}{l}\text { Ehrlichia canis, } \\
\mathrm{Ab}\end{array}$ & $\begin{array}{l}\text { Anaplasma platys, } \\
\mathrm{Ab}\end{array}$ & $\begin{array}{c}\text { Dirofilaria immitis, } \\
\mathrm{Ag}, \mathrm{PCR}, \mathrm{Ag}+\mathrm{PCR}\end{array}$ & $\begin{array}{c}\text { Hepatozoon canis, } \\
\text { PCR }\end{array}$ & $\begin{array}{c}\text { Babesia gibsoni, } \\
\text { PCR }\end{array}$ \\
\hline Overall & $14.8(12.9-16.9)$ & $7.1(5.8-8.7)$ & $\begin{array}{c}3.5(2.6-4.6), 2.3(1.58- \\
3.3), 3.9(3.0-5.1)\end{array}$ & $1.6(1.1-2.5)$ & $1.0(0.6-1.7)$ \\
\hline China & $1.9(1-3.5)$ & $0.2(-1.2)$ & 0 & $0.8(0.3-2.1)$ & $2.3(1.3-4.0)$ \\
\hline Indonesia & $36.2(27.2-46.2)$ & $11.7(6.7-19.7)$ & 0 & 0 & 0 \\
\hline Malaysia & $11.1(4.8-23.5)$ & $11.1(4.8-23.5)$ & $\begin{array}{c}6.7(2.3-17.7), 6.7(2.3- \\
17.7), 6.7(2.3-17.9)\end{array}$ & $2.2(0.4-11.6)$ & 0 \\
\hline Philippines & $33.0(25.0-42.2)$ & $17(11.1-25.0)$ & $\begin{array}{c}17.9(11.9-26.0), 13.6 \\
(8.27-21.5), 29.8(21.9- \\
39.2)\end{array}$ & $9.7(5.4-17.0)$ & 0 \\
\hline Singapore & $5.3(2.4-11.0)$ & $2.6(0.9-7.4)$ & $2.6(0.9-7.4)$ & 0 & $0.9(0.1-4.7)$ \\
\hline Taiwan & $1.5(0.42-5.4)$ & $3(1.2-7.5)$ & $\begin{array}{c}8.3(4.7-14.3), 4.8(2.07- \\
10.8), 13.2(8.0-21.0)\end{array}$ & 0 & 0 \\
\hline Thailand & $45(36.4-53.9)$ & $24.2(17.4-32.5)$ & $\begin{array}{c}4.2(1.8-9.5), 4.2(1.8- \\
9.4), 5.8(2.8-11.5)\end{array}$ & $3.3(1.3-8.3)$ & 0 \\
\hline Vietnam & $25.8(18.8-34.3)$ & $13.3(8.4-20.6)$ & $\begin{array}{c}0,0.8(0.1-4.6), 0.8(0.1- \\
4.6)\end{array}$ & $0.8(0.1-4.6)$ & 0 \\
\hline
\end{tabular}

sequencer ABI-PRISM 377 (ThermoFisher Scientific, https://www.thermofisher.com). We edited and aligned the sequences by using Geneious Prime software (https://www.geneious.com) and compared them with each other and with those available in the GenBank database by using BLAST (http://blast. ncbi.nlm.nih.gov/Blast.cgi).

\section{Statistical Analyses}

We calculated frequency values as the proportion of positive animals to the total number of examined animals and the relative frequency of occurrence of each species of parasite as the proportion of animals infested by a given parasite species/group within the total number of positive results within a given parasite species/group. We calculated 95\% CIs by using the Wilson score interval.

We categorized animals into 3 age groups $(\leq 1,>1$ to $\leq 5$, and $>5$ years). We used the $x^{2}$ test to investigate associations between parasitic infection/exposure or infestation by ectoparasites and age group or clinical observations. We analyzed the Cohen $\mathrm{K}$ coefficient and dependent and independent variables by using GraphPad Prism 8 (http:/ / www.graphpad.com). We considered $p<0.01$ to indicate significance.

\section{Results}

Our study sample consisted of 2,381 animals $(1,229$ dogs and 1,152 cats). Samples were collected from animals living in 23 main cities (and neighboring localities) in 8 countries in Asia, specifically China (Beijing, Nanjing, Shanghai, and Guangxi Province), Taiwan (Taipei, Taoyuan, Changhua, Pingtung, and Hualien), Indonesia (Jakarta, Bogor, and Yogyakarta),
Malaysia (Klang Valley region and Kota Bharu), the Philippines (Cabanatuan, San Jose, and Munoz), Singapore, Thailand (Bangkok and Chiang Mai), and Vietnam (Hanoi and Ho Chi Minh City) (Figure 1).

The dog population was composed of $565(46.0 \%)$ females, $660(53.7 \%)$ males, and $4(0.3 \%)$ with unreported data; the cat population was composed of 543 (47.1\%) females, $606(52.6 \%)$ males, and $3(0.3 \%)$ with unreported data. Ages of dogs ranged from 2 months to 20 years (mean 5.1 years, median 4.0 years), and ages of cats ranged from 2 months to 20 years (mean 2.7 years, median 2.0 years) (Table 1 ).

Overall, $42.4 \%$ (95\% CI 39.7\%-45.2\%) of dogs and $31.3 \%$ (95\% CI $28.4 \%-33.7 \%$ ) of cats had $\geq 1$ ectoparasite detected, exposure to vectorborne parasites, or both (Tables 2-6; Figures 2-6). In particular, 33.5\% (95\% CI $30.9 \%-36.2 \%$ ) of dogs and $31.3 \%$ (95\% CI $28.4 \%-$ $34.0 \%$ ) of cats were infested with $\geq 1$ ectoparasite, and $22.8 \%(95 \%$ CI $20.5 \%-25.2 \%)$ of dogs and $0.5 \%$ (95\% CI $0.2 \%-1.1 \%$ ) of cats were detected with or exposed to $\geq 1$ vectorborne parasite. T. callipaeda eyeworms were detected in $1.7 \%$ (95\% CI $0.8 \%-3.3 \%$ ) of dogs from China, specifically in $6.7 \%$ (95\% CI 3.4-12.7) of dogs and $0.6 \%$ (95\% CI $0.2 \%-1.8 \%)$ of cats from Beijing.

\begin{tabular}{lc}
\hline Table 6. Molecular identification and GenBank accession \\
numbers of vectorborne parasites detected in study of \\
ectoparasites and vectorborne zoonotic pathogens of dogs and \\
cats, Asia, 2017-2018 \\
\hline Parasite species & GenBank accession nos. \\
\hline Dirofilaria immitis filariae & MT027229 \\
Brugia malayi filariae & MT027200-1 \\
Brugia pahangi filariae & MT027202-4 \\
Leishmania infantum protozoa & MN699319-20 \\
Thelazia callipaeda nematodes & MT040339-44 \\
Hepatozoon canis protozoa & MN689651-71 \\
Babesia gibsoni protozoa & MN689634-48 \\
\hline
\end{tabular}




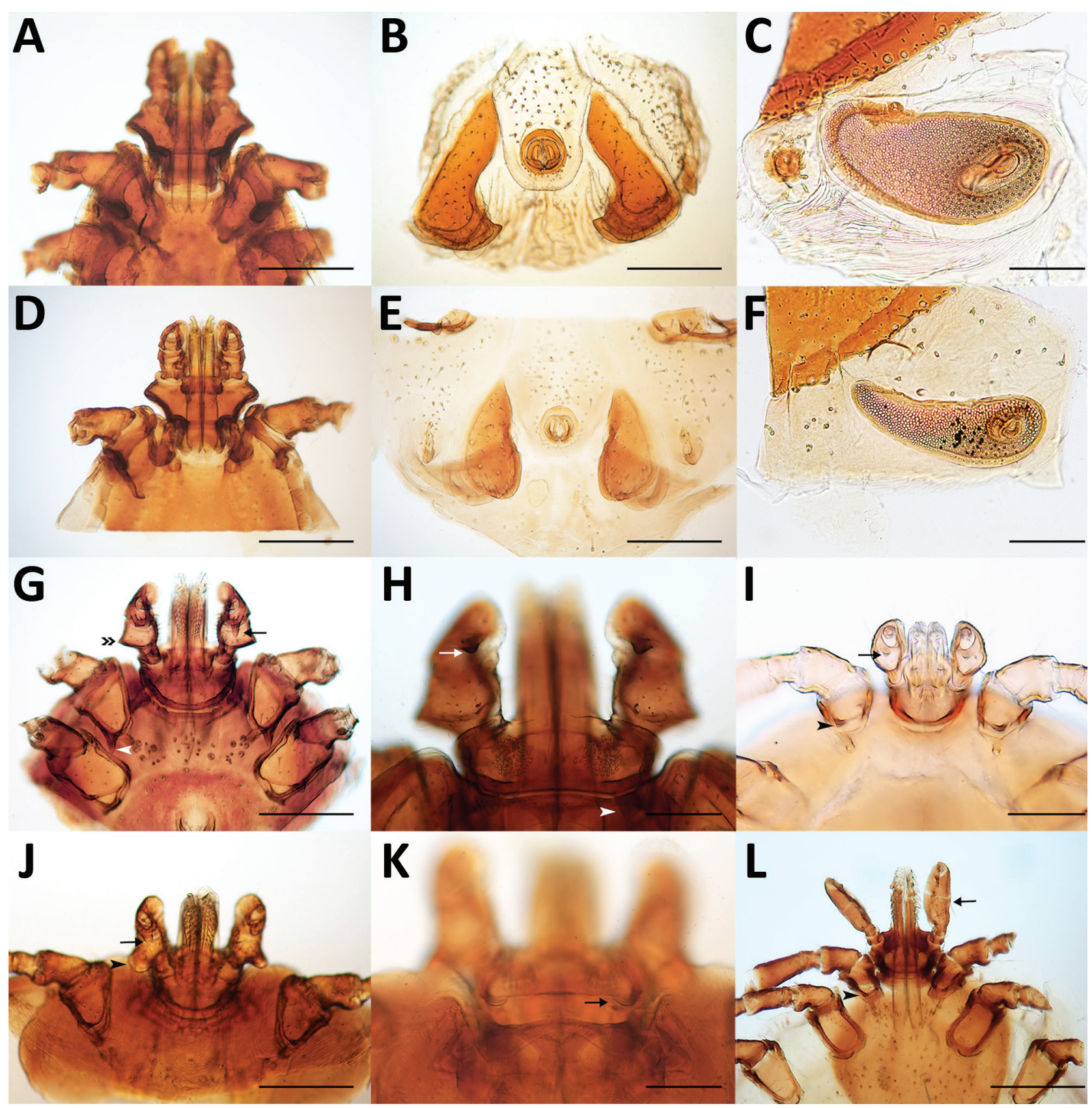

Figure 2. Morphologic characteristics of ticks collected from dogs and cats in study of ectoparasites and vectorborne zoonotic pathogens of dogs and cats in Asia, 2017-2018. A-C) Male Rhipicephalus haemaphysaloides tick with hexagonal basis capitulum (A); typical sickle-shape adanal plates (B); and spiracular plate with comma shape, broad throughout its length (C). D-F) Male R. sanguineus tick with hexagonal basis capitulum (D); subtriangular adanal plates (E); and comma-shaped spiracular plate, elongated throughout its length (F). G) Female Haemaphysalis longicornis tick with enlarged lateral palp article II (double arrowhead), ventral spur on palp article III (arrow), and internal spur on coxa I (white arrowhead), relatively long and pointed. H) $\mathrm{H}$. longicornis tick palp article III with retrograde dorsal spur (arrow) and cornua one third the length of the basis capitulum (arrowhead). I) Larva of Haemaphysalis wellingtoni palp article II slightly broader than article III, internal spur on coxa I (arrowhead) and strong and sharp ventral spur on palpal article III (arrow). J-K) Female Haemaphysalis campanulata tick with well-defined ventral spur (arrow) on palp article III, palp article II strongly salient laterally, with flared and bell-shaped posterior margin (arrowhead) $(\mathrm{J})$ and with short cornua (arrow) (K). L) Ixodes sp. female tick with long palp (arrow) and short spur on coxa I (arrowhead). Scale bars in panels A, B, D, E, G, J, and L indicate $500 \mu \mathrm{m}$; scale bars in panels C, F, H, and K indicate $200 \mu \mathrm{m}$; scale bar in panel I indicates $100 \mu \mathrm{m}$. 

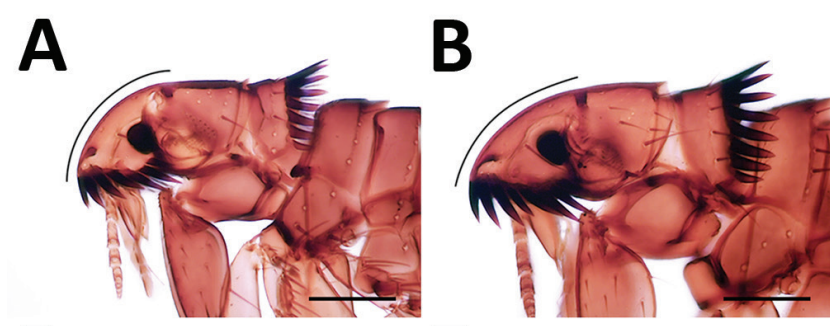

D
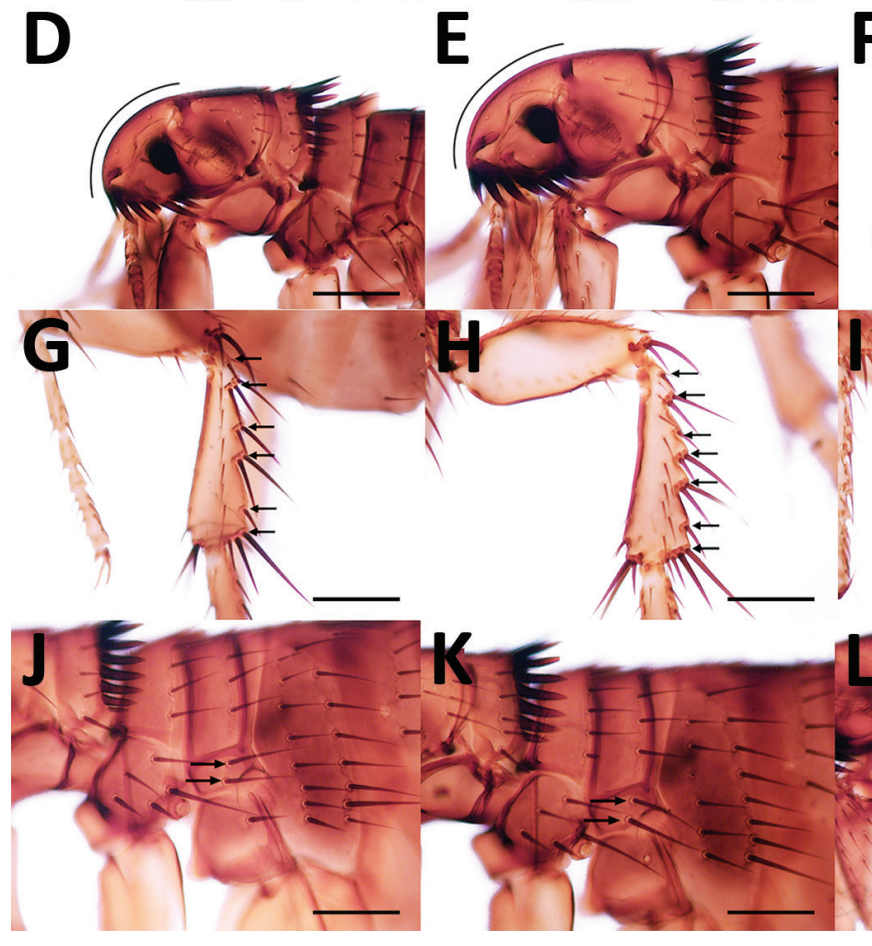

We detected co-infections with Hepatozoon canis and $D$. immitis heartworms in 4 dogs ( 2 each from Thailand and the Philippines). No tick infestations were found on dogs infected with B. gibsoni, but Rhipicephalus sanguineus ticks were detected on $50 \%$ of animals with $H$. canis infection. $H$. canis infection was correlated with infestation by $R$. sanguineus ticks $(\mathrm{p}=0.0125)$.

A total of 4 dogs $(0.3 \%, 95 \%$ CI $0.1 \%-0.8 \%)$ were positive for antibodies against Leishmania infantum; 2 of these dogs were from China $(0.4 \%, 95 \%$ CI $0.1 \%-$ $1.5 \%)$ and 1 each from Vietnam $(0.8 \%, 95 \%$ CI $0.1 \%-$ $4.6 \%$ ) and the Philippines (0.9\%, 95\% CI $0.2 \%-5.0 \%$ ). In addition, the 2 seropositive dogs from China were positive for L. infantum by qPCR and CPCR Sanger sequencing (Table 6).

A total of 2 dogs $(0.2 \%, 95 \%$ CI 0-0.6) were positive for antibodies against Borrelia burgdorferi sensu lato. One was in the Philippines $(0.9 \%, 95 \%$ CI $0.2 \%-4.9 \%)$, and 1 was in Indonesia $(1.1 \%, 95 \% \mathrm{CI}$ $0.2 \%-5.7 \%)$.

Overall, 5.2\% (95\% CI 4.1\%-6.7\%) of dogs were infected with filarial parasites according to antigen

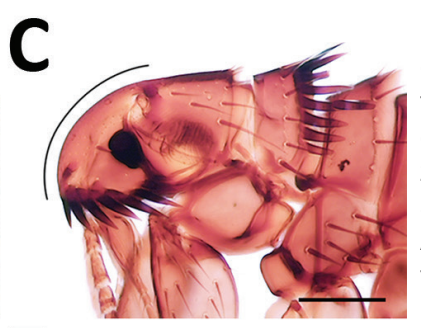

Figure 3. Morphologic

characteristics of fleas collected from dogs and cats in study of ectoparasites and vectorborne zoonotic pathogens of dogs and cats in Asia, 2017-2018. A) Ctenocephalides felis male flea head; B) C. felis female flea head showing acute anterior margin; C) C. canis male flea; D) Ctenocephalides orientis male flea; E) C. orientis female flea; F) Xenopsylla cheopis male flea with strongly rounded anterior margin and absence of ctenidia; G) $C$. felis flea with 6 setae-bearing notches (arrows) on the dorsal margin of the hind tibia; $\mathrm{H}$ ) $\mathrm{C}$. orientis flea with 7 setae-bearing notches; I) C. canis flea with 8 setae-bearing notches; J) C. felis flea with 2 setae on the lateral metonotal area (arrows); K) C. orientis flea with 2 setae; L) $C$. canis fleas with 3 setae. Scale bars indicate $200 \mu \mathrm{m}$. 


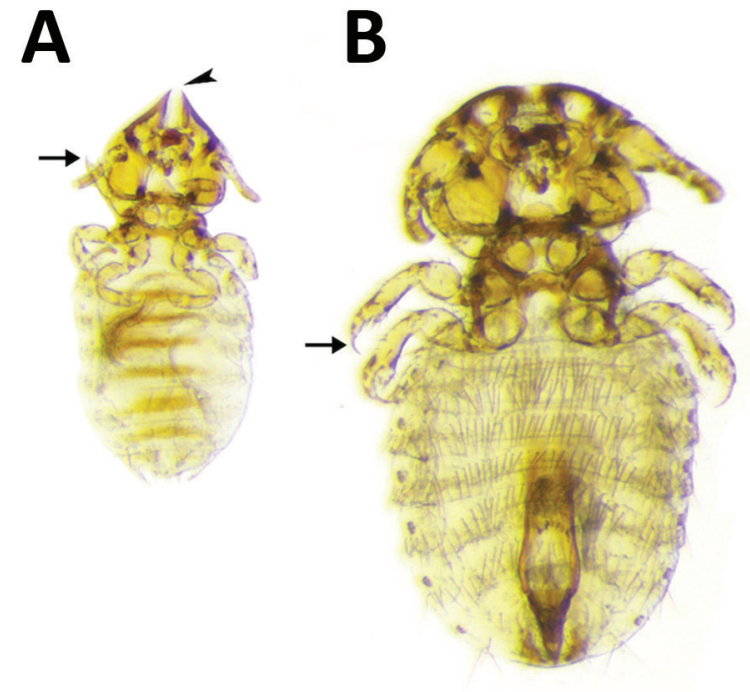

vectorborne pathogen, to ectoparasites or vectorborne parasites only, and to filarial parasites in dogs in different age classes (Appendix Figure 1). The finding of clinical signs (e.g., respiratory, lymph nodes, ocular, and skin abnormalities and increased body temperature) was statistically associated with the overall detection of/exposure to $\geq 1$ parasite (Appendix Figure 2 ) and with ectoparasite infestation or detection of/ exposure to vectorborne parasites in dogs (Appendix Figure 3). For cats, we found no association between age group and detection of parasites, whereas clinical signs (i.e., enlarged lymph nodes and skin abnormalities) were statistically associated with detection of ectoparasitic infestation (Appendix Figure 4). We found no statistical association between seropositivity for FIV antibodies and FeLV antigens and detection of ectoparasites, vectorborne pathogens, or both.

\section{Discussion}

The detection of zoonotic pathogens in client-owned dogs and cats living in metropolitan areas indicates that these animals serve as hosts for several parasitic agents in Asia. We provide data for an extended geographic distribution of zoonotic pathogens (e.g., L. infantum protozoa and zoonotic species of filariae) and of arthropods infesting animals (e.g., ticks of the Haemaphysalis and Rhipicephalus genera) where prior

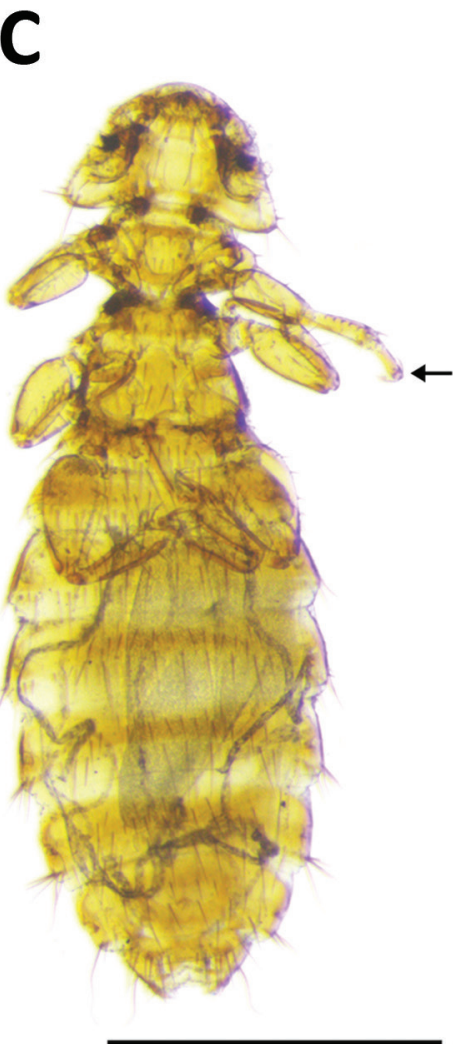

Figure 4. Chewing lice collected from dogs and cats in study of ectoparasites and vectorborne zoonotic pathogens of dogs and cats in Asia, 2017-2018. A) Female Felicola subrostratus louse with triangular head and pointed anteriorly. The median longitudinal groove (arrowhead) on the head fits around the shaft of the hair of the host. Thorax is short and legs are small, ending with a single claw (arrow). B) Trichodectes canis male louse with short thorax, flattened head with quadrangular shape, broader than long; each leg with only 1 claw on tarsus (arrow). C) Heterodoxus spiniger female louse with subtriangular head, rounded anteriorly. The thorax is considerably longer than wide. Each leg has 2 claws on the tarsus (arrow). Scale bar indicates $1 \mathrm{~mm}$.

data unavailability made treatment and disease control strategies unachievable.

Nearly half of the dogs and one third of the cats in this study were infested with $\geq 1$ ectoparasite or exposed to vectorborne pathogens; prevalence peaked in countries with a humid tropical climate (e.g., the Philippines, where $67 \%$ of dogs were infested with ticks, and Malaysia, where $89 \%$ of cats were infested with fleas). Such findings raise concern that vectorborne pathogens are responsible for several zoonotic diseases in Southeast Asia (25). The most prevalent tick on dogs and cats in this study was $R$. sanguineus. The taxonomic status of this tick group is a matter of debate with regard to $R$. sanguineus sensu lato including 2 lineages, so-called temperate and tropical (26-28). The tropical lineage of the $R$. sanguineus s.l. tick is prevalent in most countries in Asia and has been deemed accountable for the transmission of pathogens causing babesiosis, ehrlichiosis, and several rickettsial diseases in Asia $(25,29,30)$. Despite the high proportion of tick-infested animals, the paucity of data on the ecology of R. sanguineus s.l. ticks in Asia makes their role as a vector difficult to ascertain.

Unexpectedly, we found tick species not classically associated with companion animals but with the potential to transmit zoonotic disease-causing pathogens in dogs. For example, Haemaphysalis hystricis 


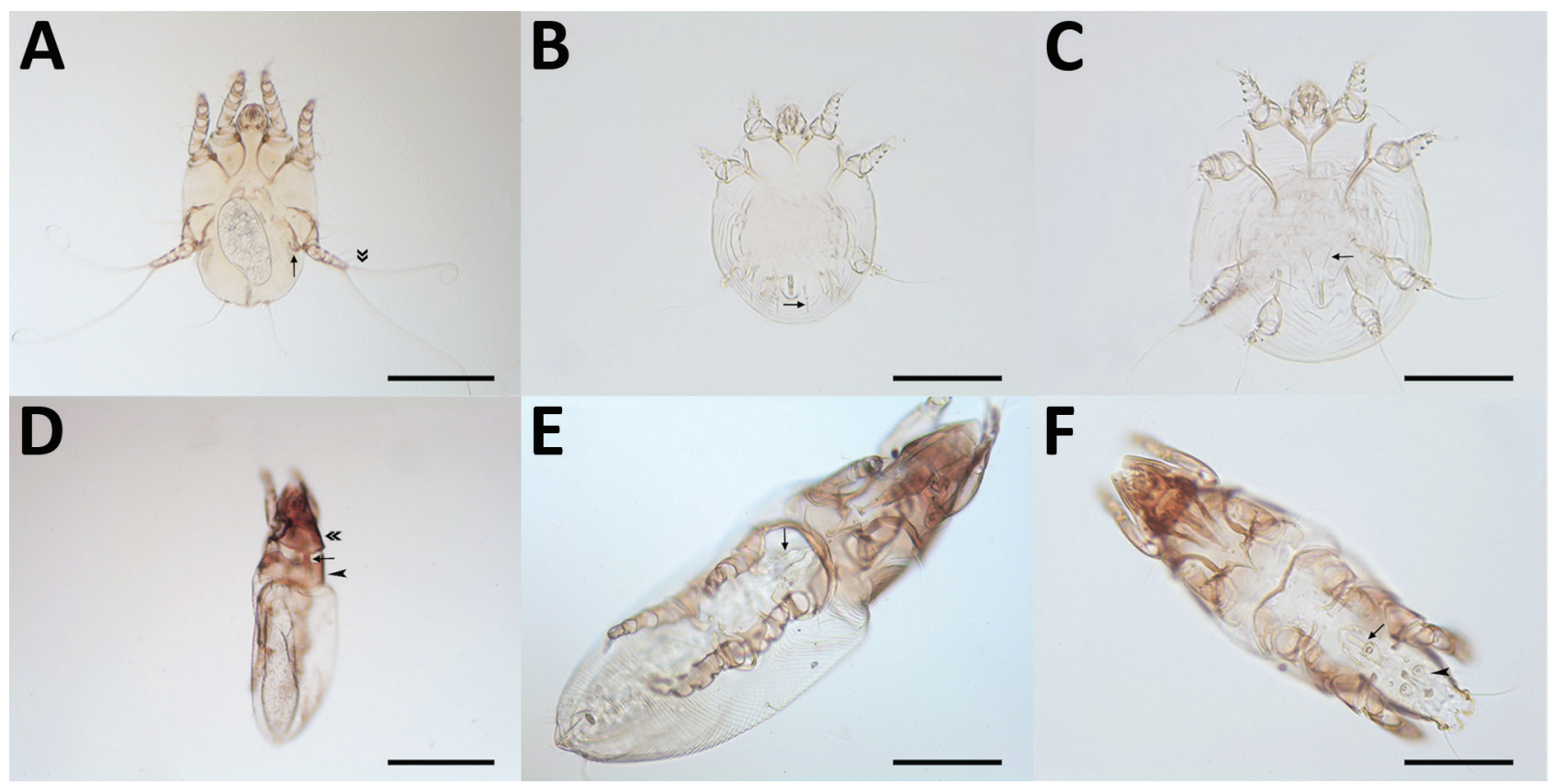

Figure 5. Mites collected from dogs and cats in study of ectoparasites and vectorborne zoonotic pathogens of dogs and cats in Asia, 20172018. A) Otodectes cynotis female mite with greatly reduced last pair of legs (arrow); the third pair of legs terminates in 2 long and whip-like setae (double arrowhead). B) Sarcoptes scabiei male mite with strong and spine-like dorsal setae (arrow). C) Notoedres cati mite with narrow and not spine-like setae. D) Female Lynxacarus radovskyi cat fur mite with cylindrical and heavily striated idiosoma, well-developed head plate (double arrowhead) with convex posterior margin; propodosomal plate (arrowhead) with posterior margin broadly rounded, connected mediodorsally to head plate by a narrow-sclerotized band (arrow). E) L. radovskyi female mite genital apparatus (arrow) positioned between coxae III in female. F) L. radovskyi male mite with genital apparatus (arrow) positioned between coxae IV (arrow) and circular genital discs (arrowhead). Scale bars in panels A and D indicate $200 \mu \mathrm{m}$; scale bars in panels B, C, E, and F indicate $100 \mu \mathrm{m}$.

ticks have been implicated as vectors of a novel Borrelia species closely related to the relapsing fever group (31), and Haemaphysalis wellingtoni ticks are vectors of Kyasanur Forest disease virus, which causes fatal epidemics among monkeys and leads to hospitalization of $\approx 500$ persons/year in India (3). Moreover, dogs seropositive to $B$. burgdorferi s.l. in this study were from Indonesia and the Philippines. This finding is unexpected, considering that these bacteria have been detected outside the known distribution area of Ixodes tick species, the main vectors of B. burgdorferi s.l., and indicates a need for in-depth epidemiologic surveys of this group of pathogens in Southeast Asia.

These results update the list of pathogens and ectoparasites affecting companion animals in Asia, including ticks with multihost feeding behavior, which has the potential to extend the network of pathogen transmission further into urban areas. The same holds true for pet dogs, suggesting that these animals might have been overlooked as potential pathogen reservoirs in metropolitan settings in this geographic area.

Similarly, the Ctenocephalides orientis flea was identified in one fifth of flea-positive dogs. The host spectrum of this flea is wider, but apparently its geographic distribution is more limited than that of the well-known cat flea Ctenocephalides felis, and it is involved in the transmission of rickettsiae, including Rickettsia sp. genotype RF2125 and Rickettsia sp. TH2014 (32,33). The morphologic ambiguity of the C. orientis flea (probably misidentified as Ctenocephalides canis and previously reported as a subspecies of $C$. felis) has contributed to a substantial dearth of information on its global distribution and role as a vector. In contrast, the cosmopolitan C. felis flea has colonized different bioclimatic niches, mainly through humanmediated migration (34). As human and animal global transportation increase in Asia, constant vigilance regarding the introduction of $C$. orientis fleas outside their known range of distribution in developed and developing countries is essential, as supported by the recent report of detection of fleas of this species in Iran (35).

In Singapore, one of the countries with the highest human development index (36) and lowest proportion of animals affected by parasites, Lynxacarus radovskyi, a mite for which little is known regarding 


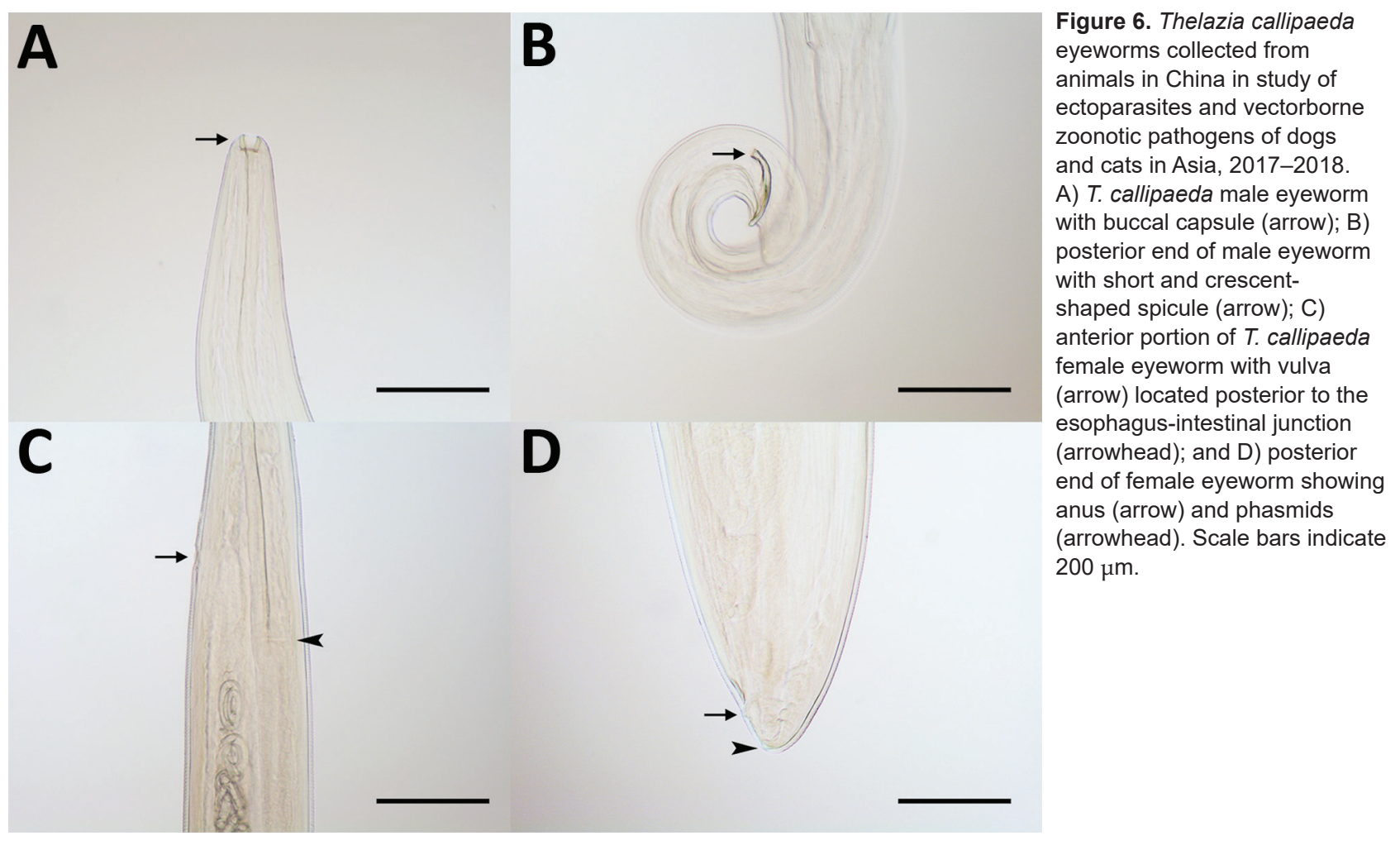

its ecology, was detected on $35 \%$ of sampled cats. We have provided molecular data and updated morphologic information on this listophorid mite, which is an agent of papular dermatitis in humans (37). Furthermore, availability of appropriate diagnostics for this species or data on the efficacy of ectoparasiticides against it are limited.

Refined diagnostics are essential for assessing the distribution of filarial species in canine populations. For instance, the poor agreement $(\kappa=0.271)$ between CPCR and antigen-detection tests for $D$. immitis advocates for the use of integrated diagnostics to better appreciate the epidemiologic status of this species of filariae. Furthermore, the use of both tests revealed B. pahangi and B. malayi to also (in addition to $D$. immitis) affect companion animals in the regions investigated. These 3 species of filariae cause clinical manifestations in humans: lymphatic filariosis for $B$. malayi and B. pahangi $(38,39)$ and pulmonary granulomas for $D$. immitis (40). In particular, lymphatic filariosis is among the most debilitating neglected tropical diseases; an estimated 70 million persons are infected, among which $>50 \%$ live in Southeast Asia $(41,42)$, and $D$. immitis infection of humans poses significant diagnostic challenges (40). Hence, for development and enactment of global elimination programs (41), surveillance of filarial species should be extended to animal populations in filariae-endemic countries (42).
Similarly, Leishmania spp. parasites currently cause $\approx 500,000$ human infections/year in 62 countries (43), although their occurrence in eastern and Southeast Asia is poorly documented. We detected dogs positive for L. infantum by serology, qPCR, and sequencing in China and seropositive dogs in Thailand and Vietnam. In Thailand, the recent emergence of L. martiniquensis and L. siamensis caused immunocompetent and immunocompromised persons to seek medical assistance (44). A range of animals is involved in the zoonotic cycle of these 2 species $(44,45)$, but dogs are the main reservoir for zoonotic leishmaniosis caused by L. infantum (46). The role of Leishmania spp. in human infections and as agents of disease in Southeast Asia requires urgent attention.

Further complicating knowledge of the transmission of zoonotic parasites in these regions of Asia are the large populations of free-roaming animals; the increased number of pet dogs and cats; and the complex social, economic, and ecologic changes currently occurring in Asia, $(1,2,4,25,47,48)$. Integrated strategies that address all of these factors are therefore fundamental for the control of such parasitic agents. We investigated the presence of pathogens and ectoparasites in pet dogs and cats living in metropolitan areas in close proximity to humans. These animals share a common environment with humans, which makes them likely key reservoirs for pathogens with 
the potential to infect persons living in such areas and settings.

The epidemiologic data presented in this study can be pivotal for building knowledge bases about the occurrence of zoonotic parasites infecting companion dogs and cats in eastern and Southeast Asia. This information could help epidemiologists and policy makers provide tailored recommendations in the blueprint of future surveillance and prevention strategies.

\section{Acknowledgments}

We are grateful to Isabelle Richtofen, Jianwei Zhang, Evonne Lim, Clair Cheng, Nadine Duperray, and Marielle Servonnet for their expertise and contributions to managing this logistically challenging study.

\section{About the Author}

Dr. Colella is a postdoctoral research fellow at the University of Melbourne, Australia. His main research is focused on the development of epidemiologic studies and strategies for interventions against zoonotic pathogens.

\section{References}

1. Coker RJ, Hunter BM, Rudge JW, Liverani M, Hanvoravongchai P. Emerging infectious diseases in southeast Asia: regional challenges to control. Lancet. 2011;377:599-609. https:/ / doi.org/10.1016/ S0140-6736(10)62004-1

2. Chongsuvivatwong V, Phua KH, Yap MT, Pocock NS, Hashim JH, Chhem R, et al. Health and health-care systems in southeast Asia: diversity and transitions. Lancet. 2011;377:429-37. https://doi.org/10.1016/ S0140-6736(10)61507-3

3. Shah SZ, Jabbar B, Ahmed N, Rehman A, Nasir H, Nadeem S, et al. Epidemiology, pathogenesis, and control of a tick-borne disease-Kyasanur Forest disease: current status and future directions. Front Cell Infect Microbiol. 2018;8:149. https://doi.org/10.3389/fcimb.2018.00149

4. Conlan JV, Sripa B, Attwood S, Newton PN. A review of parasitic zoonoses in a changing Southeast Asia. Vet Parasitol. 2011;182:22-40. https:/ / doi.org/10.1016/ j.vetpar.2011.07.013

5. Chen J, Xu MJ, Zhou DH, Song HQ, Wang CR, Zhu XQ. Canine and feline parasitic zoonoses in China. Parasit Vectors. 2012;5:152. https:// doi.org/10.1186/1756-3305-5-152

6. Inokuma H. Panorama of vector borne disease of pets in Asia \& Japan. In: Beugnet $\mathrm{F}$, editor. Guide to vector borne diseases of pets. Lyon (France): Merial; 2013. p. 94-107.

7. Traub RJ, Irwin P, Dantas-Torres F, Tort GP, Labarthe NV, Inpankaew $\mathrm{T}$, et al. Toward the formation of a Companion Animal Parasite Council for the Tropics (CAPCT). Parasit Vectors. 2015;8:271. https:/ / doi.org/10.1186/s13071-015-0884-4

8. Dong HP, Liu ZW, Chen H, Zhang LX. The situation and treatment of parasitic zoonoses of pets [in Chinese]. Hennan J Ani Sci. Vet Med. 2007;28:8-10.

9. Otranto D, Dantas-Torres F, Mihalca AD, Traub RJ, Lappin M, Baneth G. Zoonotic parasites of sheltered and stray dogs in the era of the global economic and political crisis. Trends Parasitol. 2017;33:813-25. https://doi.org/10.1016/j.pt.2017.05.013

10. Paul M, King L, Carlin EP. Zoonoses of people and their pets: a US perspective on significant pet-associated parasitic diseases. Trends Parasitol. 2010;26:153-4. https://doi.org/10.1016/j.pt.2010.01.008

11. Chomel BB, Sun B. Zoonoses in the bedroom. Emerg Infect Dis. 2011;17:167-72. https://doi.org/10.3201/eid1702.101070

12. Gibb TJ, Oseto CY. Arthropod collection and identification: field and laboratory techniques. 1st ed. Boston: Academic Press; 2006.

13. Tanskul P, Inlao I. Keys to the adult ticks of Haemaphysalis Koch, 1844, in Thailand with notes on changes in taxonomy (Acari: Ixodoidea: Ixodidae). J Med Entomol. 1989;26:573601. https:// doi.org/10.1093/jmedent/26.6.573

14. Hopkins GHE. Siphonaptera. In: Gressitt JL, editor. Insect of Micronesia. Hawaii (HI): Bishop Museum; 1961. p. 91-107.

15. Trapido H, Varma MGR, Rajagopalan PK, Singh KRP, Rebello MJ. A guide to the identification of all stages of the Haemaphysalis ticks of South India. Bull Entomol Res. 1964;55:249-70. https:/ / doi.org/10.1017/S0007485300049439

16. Yamaguti N, Tipton VJ, Keegan HL, Toshioka S. Ticks of Japan, Korea, and the Ryukyu Islands. Brigham Young University Science Bulletin. Biological Series. 1971;15:Article 1.

17. Tenorio JM. A new species of Lynxacarus (Acarina: Astigmata: Listrophoridae) from Felis catus in the Hawaiian islands. J Med Entomol. 1974;11:599-604.

18. Kettle DS. Medical and Veterinary Entomology. 1st ed. Sydney (Australia): Croom Helm; 1984.

19. Lewis RE. Fleas (Siphonaptera). In: Lane RP, Crosskey RW, editors. Medical insects and arachnids. Dordrecht (Netherlands): Springer; 1993. p. 529-575.

20. Walker JB, Keirans JE, Horak IG. The genus Rhipicephalus (Acari, Ixodidae): a guide to the brown ticks of the world. Cambridge: Cambridge University Press; 2005.

21. Wall R, Shearer D. Veterinary Entomology. 1st ed. London: Chapman \& Hall Press; 1997.

22. Otranto D, Lia RP, Traversa D, Giannetto S. Thelazia callipaeda (Spirurida, Thelaziidae) of carnivores and humans: morphological study by light and scanning electron microscopy. Parassitologia. 2003;45:125-33.

23. Oliver JH. Importance of systematics to public health: ticks, microbes, and disease. Ann Mo Bot Gard. 1996;83:37-46. https://doi.org/10.2307/2399966

24. Whiting MF, Whiting AS, Hastriter MW, Dittmar K. A molecular phylogeny of fleas (Insecta: Siphonaptera): origins and host associations. Cladistics. 2008;24:677-707. https:/ / doi.org/10.1111/j.1096-0031.2008.00211.x

25. Irwin PJ, Jefferies R. Arthropod-transmitted diseases of companion animals in Southeast Asia. Trends Parasitol. 2004;20:27-34. https:// doi.org/10.1016/j.pt.2003.11.004

26. Nava S, Mastropaolo M, Venzal JM, Mangold AJ, Guglielmone AA. Mitochondrial DNA analysis of Rhipicephalus sanguineus sensu lato (Acari: Ixodidae) in the Southern Cone of South America. Vet Parasitol. 2012;190:547-55. https:/ / doi.org/10.1016/j.vetpar.2012.06.032

27. Dantas-Torres F, Latrofa MS, Annoscia G, Giannelli A, Parisi A, Otranto D. Morphological and genetic diversity of Rhipicephalus sanguineus sensu lato from the New and Old Worlds. Parasit Vectors. 2013;6:213. https://doi.org/10.1186/1756-3305-6-213

28. Nava S, Beati L, Venzal JM, Labruna MB, Szabó MPJ, Petney T, et al. Rhipicephalus sanguineus (Latreille, 1806): neotype designation, morphological re-description of all parasitic stages and molecular characterization. Ticks Tick 
Borne Dis. 2018;9:1573-85. https://doi.org/10.1016/ j.ttbdis.2018.08.001

29. Petney TN, Keirans JE. Ticks of the genera Boophilus, Dermacentor, Nosomma and Rhipicephalus (Acari: Ixodidae) in South-east Asia. Trop Biomed. 1996;13:73-84.

30. Inpankaew T, Hii SF, Chimnoi W, Traub RJ. Canine vector-borne pathogens in semi-domesticated dogs residing in northern Cambodia. Parasit Vectors. 2016;9:253. https:/ / doi.org/10.1186/s13071-016-1552-z

31. Khoo JJ, Lim FS, Tan KK, Chen FS, Phoon WH, Khor CS, et al. Detection in Malaysia of a Borrelia sp. From Haemaphysalis hystricis (Ixodida: Ixodidae). J Med Entomol. 2017;54:1444-8. https:// doi.org/10.1093/jme/tjx131

32. Hii SF, Lawrence AL, Cuttell L, Tynas R, Abd Rani PA, Šlapeta J, et al. Evidence for a specific host-endosymbiont relationship between 'Rickettsia sp. genotype RF2125' and Ctenocephalides felis orientis infesting dogs in India. Parasit Vectors. 2015;8:169. https://doi.org/10.1186/ s13071-015-0781-x

33. Kho KL, Tay ST. Identification of rickettsial infections (Rickettsia sp. TH2014) in Ctenocephalides orientis fleas (Siphonaptera: Pulicidae). J Med Entomol. 2019;56:526-32. https://doi.org/10.1093/jme/tjy169

34. Lawrence AL, Webb CE, Clark NJ, Halajian A, Mihalca AD, Miret J, et al. Out-of-Africa, human-mediated dispersal of the common cat flea, Ctenocephalides felis: the hitchhiker's guide to world domination. Int J Parasitol. 2019;49:321-36. https://doi.org/10.1016/j.ijpara.2019.01.001

35. Seyyed-Zadeh SJ, Bozorg-Omid F, Telmadarraiy Z, Terenius O, Chavshin AR. Evidence for the presence of Ctenocephalides orientis in livestock dwellings in northwest Iran. Med Vet Entomol. 2018;32:383-7. https:/ / doi.org/ $10.1111 /$ mve. 12308

36. United Nations Development Programme. Human development indices and indicators: 2018 statistical update [cited 2019 Dec 28]. http:/ / hdr.undp.org/en/content/ human-development-indices-indicators-2018-statisticalupdate

37. Foley RH. Parasitic mites of dogs and cats. Compend Contin Educ Vet Med. 1991;13:783-800.

38. Tan LH, Fong MY, Mahmud R, Muslim A, Lau YL, Kamarulzaman A. Zoonotic Brugia pahangi filariasis in a suburbia of Kuala Lumpur City, Malaysia. Parasitol Int. 2011;60:111-3. https:// doi.org/10.1016/j.parint.2010.09.010

39. Ramaiah KD, Ottesen EA. Progress and impact of 13 years of the Global Programme to Eliminate Lymphatic Filariasis on reducing the burden of filarial disease. PLoS Negl Trop Dis. 2014;8:e3319. https:// doi.org/10.1371/journal.pntd.0003319

40. Centers for Disease Control and Prevention. Dirofliariasis FAQs [cited 2019 Dec 28]. https:/ / www.cdc.gov/parasites/ dirofilariasis/faqs.html

41. Specht S, Suma TK, Pedrique B, Hoerauf A. Elimination of lymphatic filariasis in South East Asia. BMJ. 2019;364:k5198. https:// doi.org/10.1136/bmj.k5198

42. Mallawarachchi $\mathrm{CH}$, Nilmini Chandrasena TGA, Premaratna R, Mallawarachchi SMNSM, de Silva NR. Human infection with sub-periodic Brugia spp. in Gampaha District, Sri Lanka: a threat to filariasis elimination status? Parasit Vectors. 2018;11:68. https://doi.org/10.1186/s13071-018-2649-3

43. Guerin PJ, Olliaro P, Sundar S, Boelaert M, Croft SL, Desjeux P, et al. Visceral leishmaniasis: current status of control, diagnosis, and treatment, and a proposed research and development agenda. Lancet Infect Dis. 2002;2:494-501. https:/ / doi.org/10.1016/S1473-3099(02)00347-X

44. Leelayoova S, Siripattanapipong S, Manomat J, Piyaraj P, Tan-Ariya P, Bualert L, et al. Leishmaniasis in Thailand: a review of causative agents and situations. Am J Trop Med Hyg. 2017;96:534-42. https:// doi.org/10.4269/ajtmh.16-0604

45. Chusri S, Thammapalo S, Chusri S, Thammapalo S, Silpapojakul K, Siriyasatien P. Animal reservoirs and potential vectors of Leishmania siamensis in southern Thailand. Southeast Asian J Trop Med Public Health. 2014;45:13-9.

46. Otranto D, Dantas-Torres F. The prevention of canine leishmaniasis and its impact on public health. Trends Parasitol. 2013;29:339-45. https://doi.org/10.1016/j.pt.2013.05.003

47. Huggins LG, Koehler AV, Ng-Nguyen D, Wilcox S, Schunack B, Inpankaew T, et al. A novel metabarcoding diagnostic tool to explore protozoan haemoparasite diversity in mammals: a proof-of-concept study using canines from the tropics. Sci Rep. 2019;9:12644. https:/ / doi.org/10.1038/ s41598-019-49118-9

48. Nguyen VL, Colella V, Iatta R, Bui KL, Dantas-Torres F, Otranto D. Ticks and associated pathogens from dogs in northern Vietnam. Parasitol Res. 2019;118:139-42. https:/ / doi.org/10.1007/s00436-018-6138-6

Address for correspondence: Vito Colella, Faculty of Veterinary and Agricultural Sciences, The University of Melbourne, VIC 3010, Australia; email: vito.colella@unimelb.edu.au 